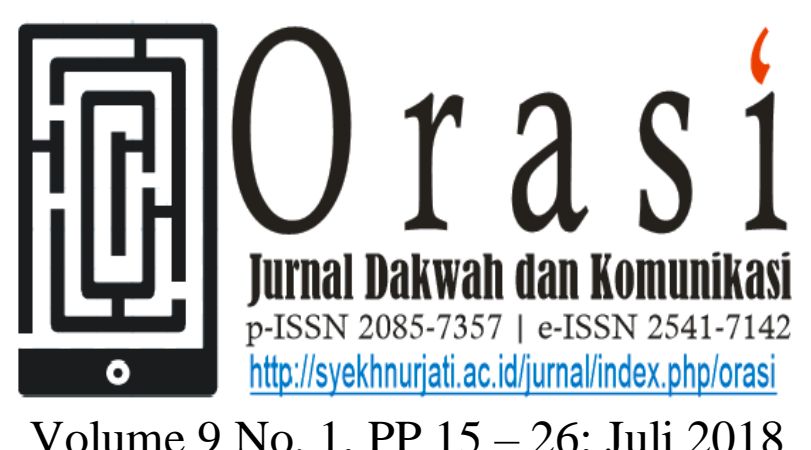

Volume 9 No. 1, PP 15 - 26; Juli 2018

\title{
PERAN KOMUNIKASI INTERPERSONAL ORANG TUA DAN ANAK DALAM MEMBERIKAN MOTIVASI BELAJAR
}

\author{
Meti ${ }^{1}$, Yayah Nurhidayah ${ }^{2(*)}$ \\ Mahasiswa Jurusan Komunikasi dan Penyiaran Islam ${ }^{1}$ \\ Dosen Jurusan Komunikasi dan Penyiaran Islam ${ }^{2}$ \\ Fakultas Ushuluddin Adab dan Dakwah IAIN Syekh Nurjati Cirebon \\ $\underline{\text { meti@syekhnurjati.ac.id }}^{1}$,yayah.nurhidayah@syekhnurjati.ac.id $^{(*)}$
}

\begin{abstract}
ABSTRAK
Masa kehidupan anak sebagian besar berada dalam lingkungan keluarga. Karena itu, keluargalah yang paling menentukan terhadap masa depan anak, begitupula corak anak dilihat dari perkembangan sosial, psikis, fisik, dan relegiusitas juga ditentukan oleh keluarga. Sebagaimana yang terjdi di blok dua desa Cisaat Kabupaten Cirebon para orang tua memperhatikan anaknya walaupun sebagian besar kesibukan sebagai ibu rumah tangga tidak mengurangi perhatian terhadap sang anak pada pendidikannya. Penelitian ini bertujuan untuk mengetahui bagaimana komunikasi interpersonal yang dilakukan orang tua dengan anak dalam kehidupan sehari-hari, bagaimana imbauan pesan orang tua terhadap anak dalam memberikan motivasi belajar, serta sejauh mana efektifititas imbauan pesan orang tua dalam memberikan motivasi belajar anak. Metodologi yang digunakan adalah jenis penelitian kualitatif, adapun pendekatannya menggunakan studi kasus. Sedangkan teknik pengumpulan datanya adalah wawancara, pengamatan, dan dukumentasi. Hasil penelitian ini di simpulkan bahwa peran komunikasi interpersonal yang terjadi antara orang tua dengan anak adalah adanya sebuah keakraban antara orang tua dan anak, adanya kesepakatan yang terjalin antara orang tua dan anak, ketepatan respon orang tua terhadap anak maupun sebaliknya, dan nada bicara yang tepat ketika melakukan komunikasi dengan anak maupun sebaliknya. Sementara itu imbauan pesan dilakukan dengan cara menyampaikan pesan berulang-ulang, menggunakan bahasa yang lugas dan jelas, dan memberikan contoh suri tauladan kepada sang anak, adapun efektifitas terwujud dikarenakan adanya waktu situasi dan tempat yang tepat dan konsistensi dari orang tua.
\end{abstract}

Kata kunci: imbauan; interpersonal; orang tua; anak; motivasi belajar 


\section{PENDAHULUAN}

Anak termasuk individu unik yang mempunyai eksistensi dan memiliki jiwa tersendiri, serta mempunyai hak untuk tumbuh dan berkembang secara optimal sesuai dengan iramanya masingmasing yang khas. Masa kehidupan anak sebagian besar berada dalam lingkungan keluarga. Karena itu, keluargalah yang paling menentukan terhadap masa depan anak, begitupula corak anak dilihat dari perkebangan social, psikis, fisik, dan relegiusitas juga ditentukan oleh keluarga. Rasulullah SAW bersabda yang artinya: "tidaklah seorang anak dilahirkan melainkan ia dilahirkan dalam keadaan fitrah, kedua orangtuanyalah yang membuatnya yahudi, nasrani maupun majusi.”(H.R.Bukhari Muslim). Orangtua mempunyai tanggung jawab untuk mengangtarkan putra-putrinya menjadi seorang yang sukses dan bagi orangtua penting memahami dan memperlihatkan perkembangan anaknya (Hidayah 2009: 15).

Keluarga merupakan lembaga sosialisasi yang pertama dan utama bagi seorang anak. Melalui keluarga anak belajar berbagai hal agar kelak dapat melakukan penyesuaian diri dengan budaya di lingkungan tempat tiggalnya . orang tua memegang peran penting dalam proses sosialisasi yang dijalani seorang anak. Sebagaimana diungkapkan Arnett (1995), proses sosalisasi merupakan proses seorang anak belajar tentang perilaku dan keyakinan tentang dunia tempat ia tinggal. Seiring tumbuh kembangnya anak mulai mengenal dunia yang lebih luas selain keluarga, sehingga sumber sosialisasi bagi anak pun semakin beragam. Selain keluarga, anak mulai mengenal teman sebaya, media, sekolah, komunitas, sistem hukum, dan sistem keyakinan dalam budaya. (Lestari, 2012: 121).

Dalam pengertian psikologis, keluarga merupakan sekumpulan orang yang hidup bersama dalam tempat tinggal bersama dan masing-masing anggota merasakan adanya pertautan batin sehingga terjadi saling mempengaruhi, saling memperhatikan dan saling menyerahkan diri. Keutuhan orang tua (ayah dan ibu) dalam sebuah keluarga sangat dibutuhkan dalam membantu anak dalam mengebangan kreatifitas diri. Keluarga dikatakan utuh apabila di samping lengkap anggotanya terutama anak-anaknya. Jika dalam keluarga terjadi kesenjangan hubungan, perlu diimbangi dengan kualitas dan 
intensitas hubungan sehingga ketidak adaan ayah dan ibu di rumah tetap dirasakan kehadirannya dan dihayati secara psikologis. (Sochib, 2000: 15)

Kesibukan ibu rumah tangga di Desa Cisaat Kecamatan Dukupuntang Kabupaten Cirebon tidak mengurangi perhatian mereka terhadap pendidikan anak, namun dengan segala keterbatasan yang dimiliki tentunya berpengaruh terhadap pendidikan anak. Oleh karena itu dalam kesempatan penelitian ini penulis ingin meneliti sampai sejauh mana perhatian orang tua dalam membimbing anak di bidang pendidikan yang ada di Desa Cisaat Kecamatan Dukupuntang Kabupaten Cirebon sebagai orang tua murid, dan sejauh mana pengaruh yang ditimbulkan terhadap pendidikan anak mereka.

Berdasarkan latar belakang di atas, menjadi daya tarik bagi penulis untuk melakukan penelitian yang berjudul: "Peran Komunikasi Interpersonal Orang tua - Anak dalam Memberikan Motivasi Belajar" dengan rumusan masalah di antaranya bagaimana komunikasi interpersonal yang dilakukan orang tua dengan anak dalam kehidupan sehari-hari, bagaimana imbauan pesan orang tua terhadap anak dalam memberikan motivasi belajar, dan sejauhmana efektifititas imbauan pesan orang tua terhadap anak dalam memberikan motivasi belajar

\section{METODOLOGI PENELITIAN}

Dalam penelitian yang dilakukan ini menggunakan jenis penelitian kualitatif. Menurut Bogdan dan Taylor dalam bukunya Lexy J. Moleong, mendefinisikan metodologi kualitatif sebagai prosedur penelitian yang mengasilkan data deskriptif berupa katakata tertulis atau lisan dari orang-orang dan perilaku yang dapat di amati. Dalam penelitian kualitatif metode yang biasanya dimanfaatkan adalah wawancara, pengamatan, dan pemanfaatan dokumen. (Moleong, 2004:4-5). Dengan penelitian ini diharapkan dapat mendeskripsikan tentang Peran Komunikasi Interpersonal Orang tua- anak Terhadap Motivasi Belajar.

Pendekatan penelitian ini menggunakan pendekatan studi kasus yang merupakan suatu metode menyelidiki atau mempelajari suatu kejadian mengenai perorangan. Pada metode studi kasus ini diperlukan banyak informasi guna mendapatkan bahan- 
bahan yang agak luas. Metode ini merupakan integritas dari data yang diperoleh dengan metode lain (Muhadjir, 1996; hal. 42)

Sumber data yaitu dari mana data tersebut di peroleh, data primer dan data sekunder.

a)

Data primer yakni data yang diperoleh dari hasil wawancara dengan informan yang berhubungan dengan penelitian. Yaitu antara orang tua dengan anak.

b)

Data sekunder yakni data yang diperoleh dari literatur yang mendukung dataprimer, seperti kamus, internet, artikel,buku-bukuyang berhubungan dengan penelitian dan sebagainya.

Teknik pengumpulan data yang yang dimaksud adalah cara atau pola yang harus dilakukan untuk memperoleh data atau informasi. Sehingga untuk memperoleh data yang digunakan dalam penelitian ini adalah data studi lapangan dengan menggunakan cara sebagai berikut:

a.

Observasi

Observasi atau pengamatan adalah metode pengumpulan data yang digunakan untuk menghimpun data penelitian melalui pengamatan dan pengindraan. (Bungin, 2007; hal. 110)

Teknik observasi ini akan peneliti gunakan untuk mengamati bagaimana proses penyampaian pesan yang di sampaikan oleh orang tua kepada anaknya dalam memberikan motivasi belajar.

b. Interview)

Wawancara (Indept

Wawancara adalah teknik proses memperoleh keterangan untuk tujuan penelitian dengan cara tanya jawab sambil bertatap muka antara pewawancara dan informan. (Bungin, 2007; hal. 111)

Penelitian ini menggunakan metode wawancara mendalam (IndepthInterview). Wawancara Mendalam (Indepth-Interview) merupakan metode pengumpulan data yang sering digunakan dalam penelitian kualitatif. Teknik wawancara ini akan peneliti gunakan untuk meneliti tentang bagaimana orang tua memberikan motivasi belajar kepada anaknya, adapun pertanyaan yang akan ditanyakan yaitu: Apa saja strategi komunikasi yang dilakukan orang tua dalam memberikan motivasi belajar terhadap anak, Bagaimana peran komunikasi orang tua dalam memberikan motivasi belajar 
terhadap anak.

c. Dokumentasi

Dokumentasi adalah salah satu metode pengumpulan data yang digunakan dalam metodologi penelitian sosial untuk pengumpulan data, karna sejumlah besar fakta dan data sosial tersimpan dalam bahan yang berbentuk dokumentasi. (Burhan Bungin, 2007; hal. 124)

\section{Dalam penelitian ini teknik dokumentasi digunakan untuk memperoleh data-data sebagai berikut:}

a) Jumlah orang tua yang mempunyai anak sekolah

b) Data penduduk Desa Cisaat

c) Lokasi penelitian.

d. Informan

Informan penelitian di dalam penelitian kualitatif berkaitan dengan bagaimana langkah yang di tempuh peneliti agar data atau informasi dapat di perolehnya. Menentukan informan bisa dilakukan oleh peneliti apabila peneliti memahami masalah umum penelitian serta memahami pula anatomi masyarakat dimana penelitian itu dilaksanakan. Namun apabila peneliti belum memahami anatomi masyarakat tempat penelitian,maka peneliti berupaya agar tetap mendapatkan informan penelitian. (Bungin,2007:107)

\section{HASIL DAN PEMBAHASAN}

Komunikasi yang dilakukan orang tua dengan anak yang ada di Desa Cisaat ini menggunakan teori hubungan interpersonal dimana model komunikasi interaksional memandang hubungan interpersonal sebagai suatu sistem, yang dimana setiap sistemnya memiliki sifatsifat struktural, integrative dan medan untuk memahami sistem harus melihat struktur selanjutnya kecenderungan untuk memelihara dan mempertahankan kesatuan tersebut.(Rakhmat, 2005: 124)

Banyak para orang tua atau ibu rumah tangga yang tak banyak mengetahui bahwa komunikasi dengan anak merupakan sesuatu yang sangat penting dalam menjaga hubungan dengan sang anak. Komunikasi antara orang tua dan anak adalah sebuah proses pengiriman pesan yang dapat diterima sama dengan pesan yang dikirim.

Komunikasi yang terjadi antara orang tua dan anak yaitu komunikasi hubungan interpersonal karena mereka saling memahami dan memberikan bantuan satu sama lain kalimat - kalimat yang disampaikan sekali lagi bukan 
hanya menyampaikan isi tetapi juga mendefinisikan suatu hubungan interpersonal.dan dari jawaban tersebut pula mendidik dengan rasa sabar dan penuh kasih sayang pada sang anak adalah kunci utama dalam berkomunikasi dengan sang anak dengan adanya rasa sabar dan penuh cinta terhadap anak menjaikan anak terbuka dan mengungkapkan pikiran kepada orang tua, sehingga akan terjalin hubungan yang akrab dan berlangsung secara mendalam, adapun cara menumbuhkan rasa sabar dan cinta kasih sayang hubungan interpersonal tidaklah bersifat statis, tetapi selalu berubah, untuk mempertahankan supaya tidak berubah memerlukan tindakan tertentu untuk mengebalikan keseimbangan. Ada empat yamg perlu dipelihara pada keseimbagan ini, yaitu: keakraban, kontrol, respon yang tepat dan nada emosional yang tepat. (Rakmat, 2005: 129)

\section{Keakraban}

Keakraban merupakan salah satu pemenuhan akan kebutuhan kasih sayang. Hubungan interpersonal antara orang tua dan anak akan terpelihara apabila kedua belah pihak sepakat tentang tingkat keakraban yang diperlukan dalam menjalin komunikasi dengan lawannya seperti dari hasil pengamatan anak cenderung menjadi komunikator atau komunikan yang aktif terlihat dalam kehidupan sehari-hari meskipun memakai bahasa sunda anak bisa berkomunikasi secara interaktif. (Rakhmat, 2005: 131)

Peneliti banyak melihat terjadinya proses komunikasi pada orang tua di Desa Cisaat. Pola komunikasi yang terjadi antara ibu Rundasih dan ibu Eni ketika berinteraksi langsung dengan anaknya yaitu tahap dalam hubungan interpersonal yang dimana peneguhan hubungan interpersonal yang bersifat statis, tetapi selalu berubah, untuk mempertahankan supaya tidak berubah memerlukan tindakan tertentu untuk mengembalikan keseimbangannya.

\section{Kesepakatan}

Kesepakatan tentang siapa yang akan mengontrol siapa, dan bilamana. Jika dua orang mempunyai pendapat yang berbeda sebelum mengambil kesimpulan, siapakah yang harus berbicara lebih banyak, siapa yang menentukan, siapakah yang dominan. Konflik terjadi umumnya bila masingmasing ingin berkuasa, atau tidak ada 
pihak yang mau mengalah. (Rakhmat, 2005: 132)

Dari beberapa informan yang sudah peneliti wawancarai bisa di tarik kesimpulan bahwa proses komunikasi yang di lakukan orang tua dan anak yang ada di Desa Cisaat termasuk kedalam komunikasi interpersonal, yaitu peneguhan hubungan interpersonal

\section{Ketepatan respon}

Ketepatan respon yang dimana respons A harus di ikuti respon $\mathrm{B}$ yang sesuai. Misalnya dalam percakapan, pertanyaan yang harus di sambut dengan jawaban, lelucon dengan tertawa, permintaan keterangan dengan jelas. Respon disini bukan saja berkenaan dengan pesan-pesan verbal tetapi juga pesan-pesan nonverbal. (Rakhmat, 2005 126)

Dari hasil pengamatan informan saudari Sanda dan saudara Wahyu memiliki komunikasi yang sama ketika di rumah atau ketika berkomunikasi dengan orang tuanya mereka mengerti maksud yang di samapikan orang tua padanya sehingga tidak ada hambatan komunikasi dalam berinteraksi dengan orang tuanya.

\section{Nada bicara yang tepat}

Nada emosional yang tepat dalam komunikasi interpersonal atau komunikasi antar pribadi di sini komunikasi yang secara tatap muka atau komunikasi yang langsung anatara dua orang dan menagkap reaksi secara langsung. (Rakhmat, 2005: 124). Dan komunikasi orang tua dan anak yang ada di Desa Cisaat Kecamatan Dukupuntang Kabupaten Cirebon sudah mengerti dan terjalin dengan baik walaupun kadang masih ada sedikit hambatan yang terjadi ketika berkomunikasi.

Dari hasil pengamatan juga bahwa komunikasi antara orang tua dan anak ketika berada di rumah bahwa setiap kita melakukan komunikasi, bukan hanya sekedar menyampaikan isi pesan namun juga menentukan kadar hubungan interpersonal antara orang tua dan anak, karena jika saja kadar hubungan antara anak tidak ada komunikasi pun akan terhambat dan hubungan orang tua anakpun menjadi tidak harmonis (Rakhmat, 2005: 121).

Nada komunikasi yang tepat juga akan mempengaruhi pola komunikasi yang terjadi dan banyak aspek yang akan terjadi pada tumbuh kembang sang anak jika nada pesan orang tua terdengar kasar 
atau lembut yang nanti ketika dewasa menjadikan anak berkarakter seperti orang tuanya ketika berkomunikasi dengan anak. (Lestari, 2012: 51)

Di tarik kesimpulan bahwa pola komunikasi yang di lakukan orang tua dan anak yang ada di Desa Cisaat ini dalam melakukan interaksi atau komunikasi dengan anak para orang tua mempunyai caranya masing-masing, dan setiap para orang tua memiliki karakter yang berbeda sehingga cara berinteraksi dengan anakpun berbeda pula, yang dilakukan oleh para orang tuapun sangat beragam.

Namun faktor utama yang harus dimiliki para orag tua adalah harus adanya rasa sabar orang tua dalam berkomunikasi dengan anak menggunakan komunikasi interpersonal dan peneguhan hubungan interpersonal.

Imbauan pesan yang terjadi antara orang tua dan anak dalam memberikan motivasi belajar, imbauan pesan itu sendiri bila pesan-pesan kita yang dimaksudkan untuk mempengaruhi orang lain maka kita harus menyentuh motif yang menggerakan atau mendorong prilaku komunikate. Dengan perkataan lain untuk mengimbau agar bisa di terima dan melaksanakan gagasan yang di sampaikan.

Dan menjadi orang tua merupakan salah satu harapan yang dijalani oleh pasangan yang memiliki anak. Anakanak menjalani proses tumbuh kembang dalam suatu lingkungan dan hubungan di mana anak tumbuh dan berkembang yaitu di kelurganya dan hubungan yang terjalin pasti dengan orang tuanya. (Lestari, 2012: 16)

Begitu halnya yang terjadi dengan orang tua dan anak yang ada di blok dua Desa Cisaat di mana imbauan pesan orang tua tentunya memiliki respon yang berbeda terhadap anaknya. Di antara motif atau pendorong supaya imbauan pesan terjalin seperti yang di inginkan maka ada beberpa hal yang harus terjadi di antaranya:

\section{Penyampaian Pesan Berulang-ulang}

Penyampaian pesan yang berulangulang menjadi salah satu faktor yang penting dalam memberikan sebuah imbauan pesan terlebih orang tua terhadap anaknya. Kedekatan pengasuhan orang tua dan anak menunjukan bahwa hubungan orang tua dan anak akan bersifat interaksional. Artinya, perilaku orang tua, akan 
mempengaruhi perilaku anak dan afeksi, kepedulian, kenyamanan, sebaliknya perilaku anak akan perhatian, perawatan, dukungan, dan memengaruhi respons orang tuanya. cinta.mendefinisikan pengaruh perilaku Pengasuhan dalam hal ini merupakan kerja interaksional yang berlangsung sepanjang waktu dan bersifat dinamis. Pendekatan interaksi orang tua-anak memfokuskan pada hubungan dua pihak dan memandang hubungan orang tuaanak sebagai bagian dari suatu keseluruhan.

\section{Menggunakan Bahasa yang Lugas dan Jelas}

Hubungan orang tua anak yang membuat anak merasa dicintai dan mengembangkan rasa percaya diri. Kehangatan yang terjalin memberikan konteks bagi afeksi positif yang akan meningkatkan mood untuk peduli dan tanggap terhadap satu sama lain. Kualitas hubungan yang terjalin antara orang tua dan anak pun menjadi seperti yang di inginkan. (Lestari, 2012: 49)

Pengaruh prilaku orang tua juga sangat berpengaruh dalam tubuh kembang seorang anak. Bowlby (1969), Dimensi kehangatan merupakan suatu rentang kontinum, yang di satu sisi ditandai oleh penerimaan yang mencakup berbagai perasaan dan perilaku yang menunjukan kehangatan,

pengasuhan sebagai faktor kunci dalam hubungan orang tua anak yang di bangun sejak usia dini.(Lestari, 2012: 17)

\section{Memberikan Contoh Suri Tauladan Kepada Sang Anak}

Memberikan contoh suri tauladan kepada sang anak menjadi salah satu faktor keberhasilan orang tua dalam memberikan imbauan pesan kepada sang anak dan Selain emosi yang kuat hubungan orang tua dan anak juga dapat dijelaskan dengan pendekatan teori penerimaan dan penolakan orang tua menurut Rohner dkk juga persepsi anak terhadap penerimaan dan penolakan orang tua atau sosok signifikan yang lain akan mempengaruhi perkembangan kepribadian individu dan mekanise yang di kembangkan dalam menghadapi suatu masalah yang sedang di hadapi.

Efektivitas imbauan pesan orang tua terhadap anaknya dalam memberikan motivasi belajar. Dalam sebuah komunikasi tentunya memiliki efektivitas penyampaian sebuah pesan. Namun pada kenyataannya komunikasi yang efektiv tidaklah mudah karena semua orang belum tentu bisa melakukan komunikasi 
secara efektiv apalagi orang tua terhadap anak atau sebaliknya anak pada orang tua yang kadang tidak sesuai apa yang di inginkan.(Mulyana, 2013:50)

\section{Waktu Yang Tepat}

Waktu adalah sebuah perencanaan dan pengawasan sebab waktu menjadi salah satu sumber daya untuk melakukan sebuah pekerjaan yang harus di kelola secara efektif dan efesien yang harus di miliki orang tua dan anak.

Sebab harus adanya sikap sabar orang tua dan waktu yang tepat untuk memberikan motivasi pada anaknya. Namun orang tua juga perlu mengetahui bahwa anak juga memiliki haknya.

\section{Situasi Yang Tepat}

Situasi yang tepat membuat keadaan yang ada pada diri sendiri baik itu di luar maupun di dalam dirinya, dan sebagai orang tua harus mempunyai cara unuk membuat situasi yang tepat agar ketika memberikan motivasi dengan sang anak dan juga gaya dari pengasuhan yang biasanya di lakukan oleh orang tua yang terlalu baik, situasi yang tepat juga akan cenderung memberi banyak kebebasan pada anak-anak dengan menerima dan memaklumi segala perilaku, tuntutan dan tindakan anak, namun kurang menuntut sikap tangggung jawab dan keteraturan perilaku anak (Lestari, 2012: 48).

Harapan semua orang tua yang ada di blok dua Desa Cisaat pada anaknya sederhana saja, pertama orang tua mengharapkan anaknya menjadi anak yang sholeh dan harapan kedua menjadi orang yang sukses. Namun menjadi orang yang sukses butuh peoses yaitu dengan belajar.

Namun bagi kebanyakan siswa, belajar berarti menggaris bawahi buku pelajaran dengan stabile berwarna warni sambil mendengarkan musik dari ruangan lain. Atau apabila menghadapi ujian semester esok harinya, belajar berarti minum kopi sebanyak mungkin atau meminum pil anti ngantuk dan menghabiskan sepanjang malam untuk menjejali otaknya dengan semua bahan ajaran yang sudah di ajarkan yang seharusnya dipelajari selama kurang lebih dua belas minggu sebelumnya. (Rifa hidayah, 2009: 30)

Begitu pula orang tua yang ada di blok dua Desa Cisaat Kecamatan Dukupuntang Kabupaten Cirebon yang tentunya dalam mengajak anak untuk terus belajar di butuhkan motivasi yang kuat dan rasa sabar yang tinggi. 


\section{KESIMPULAN}

Berdasarkan hasil penelitian dan pembahasan mengenai peran komunikasi interpersonal orang tua-anak dalam memberikan motivasi belajar yang telah diuraikan, maka dapat ditarik kesimpulan dari penelitian sebagai berikut: Komunikasi interpersonal yang dilakukan orang tua dengan anak dalam kehidupan sehari-hari. Jika dilihat dari hasil wawancara diatas dapat disimpulkan bahwa ada beberapa cara yang di lakukan oleh para orang tua dalam melakukan interaksi atau melakukan komunikasi dengan anaknya yaitu adanya sebuah keakraban antara orang tua dan anak, adanya kesepakatan yang terjalin antara orang tua dan anak, ketepatan respon orang tua terhadap anak maupun sebaliknya, dan nada bicara yang tepat ketika melakukan komunikasi dengan anak maupun sebaliknya. Imbauan pesan orang tua terhadap anak dalam memberikan motivasi belajar. Dari hasil wawancara yang sudah dilakukan peneliti menarik kesimpulan bahwa orang tua menjalin kedekatan dengan anak agar pesan terjalin sesuai yang di inginkan maka para orang tua harus bisa menyampaikan pesan secara berulang-ulang, menggunakan bahasa yang lugas dan jelas dan memberikan contoh suri tauladan kepada sang anak dalam hal memberikan imbauan pesan pada anak.

Efektivitas imbauan pesan orang tua terhadap anak dalam memberikan motivasi belajar. Dengan melihat hasil wawancara dengan beberapa informan, penulis menyimpulkan bahwa efektivitas imbauan pesan orang tua terhadap anak dalam memberikan motivasi belajar adalah orang tua harus mempunyai waktu yang tepat, situasi yang tepat dan tempat yang tepat agar anak menjadi tidak pemalu dan mau belajar.

\section{DAFTAR PUSTAKA}

Bungin, Burhan. 2007. Penelitian kualitatif. Jakarta: Kencana Prenada Media Group. B.Uno Hamzah. 2006. Teori motivasi dan pengukurannya. Jakarta: PT Bumi Aksara.

Emzir. 2012. Metodologi Penelitian Kualitatif, Analisis Data. Jakarta: PT. Rajagrafindo Persada Offset.

Moleong, Lexy J. 2004. Metodologi Penelitian Kualitatif. Bandung: Remaja Rosdakarya.

Muhadjir, Noeng. 1996. Metodologi Penelitian kualitatif. Yogyakarta: PT.

Bayu Indra Grafika.

Mulyana, Deddy. 2006. Metodologi Penelitian Kualitataif. Bandung: 
PT Remaja Rosdakarya.

Mulyana, Deddy. 2010. Ilmu Komunikasi. Bandung. PT Remaja Rosdakarya. Lestari Sri. 2012. psikologi keluarga.

Surakarta. Kencana Prenada Media Group

Sardiman A.M, 2007. Interaksi dan motivasi belajar mengajar. Jakarta: Raja Grafindo Persada.

Sochib, Moh. 2000. Pola asuh orang tua dalam membantu anak mengebangkan disiplin diri. Jakarta: Rineka Cipta.

Suciati. 2014. KomunikasiInterpersonal. Yogyakarta:

BukuLiteraYogyakara HidayahRifa. 2009.

Psikologipengasuhananak. Malang: UIN-Malang Pers

Mulyana dedi, 2013. Ilmu Komunikasi suatu pengantar. Bandung, PT Remaja Rosda Karya
Rakhmat Jalaluddin. 2005. Psikologi Komunikasi. Bandung. PT. Remaja Rosda Karya

Lestari Sri. 2012. Psikologi Keluarga penanaman nilai penanganan konflik dalam keluarga. Yogyakarta. Kencana Prenada Media Group

Sardiman A.M. 2012. Interaksi dan Motivasi Belajar Mengajar. Jakarta. PT. Raja Grafindo Persada

Syah Muhibbin. 2002. Psikologi Belajar. Jakarta. PT. RajaGrafindo Persada

Sobur Alex. 2013. Psikologi Umum Dalam Lintas Sejarah. Bandung. Pustaka Setia

Siregar Eveline dan Nara Hartini. 2010. Teori Belajar dan Pebelajaran. Ghalia Indonesia. Jakarta 